\title{
AWAIRNESS RAISING EXPERIENCE IN EFFORTS TO IMPROVE THE WELFARE OF PERSONS WITH DISABILITIES THROUGH THE ROLE OF THE COMMUNITY-BASED REHABILITATION GROUP IN THE STUDENT COURSE WORK OF COMMUNITY LEARNING PROGRAMS
}

\author{
Arni Surwanti \\ Universitas Muhammadiyah Yogyakarta \\ arni.umy@gmail.com
}

\begin{abstract}
Unavailability of valid data and lack of identity cards causes PwDs to be unable to obtain services from in government programs. Health insurance programs, educational programs, vovational training program and economic empowerment programs are inaccessible to PwDs. This is what makes the welfare of persons with disability still in a state of apprehension. The Student Course Work of Community Learning Programs (Kuliah Kerja Nyata Program Pembelajaran Masyarakat/KKN-PPM) is expected to provide a model to address these issues by providing awareness raising activities in improving the capacity of village government and village communities through community organizations existing in their roles to improve the welfare of persons with disabilities. Method or concept of activities to be used to solve the problem is the first step will be done are: First, organizing community-based rehabilitation groups. Second, strengthening of community-based rehabilitation groups, by providing disability awareness training, introducing legislation related to the protection and fulfillment of the rights of persons with disabilities, Planning program of community-based rehabilitation groups to ensure persons with disabilities receive services in accordance with their needs. Third, Pilot Project of communitybased rehabilitation groups by conducting activities: Data collection and assessment of the needs of PwDs in Baturetno Village; Economic empowerment of PwDs and their families. The strengthening of business groups of persons with disabilities is done through the provision of entrepreneurial knowledge and business management. So that with existing skills, PwDs can run their business; Strengthening is also provided on savings and loan activities through savings and loan management training. To support the acceleration of the run of community-based rehabilitation groups, it is necessary to provide assistances in the preparation of programs and activities. To become a program sustainability, future activities can use village budget, sub-district district budget funds with community-based rehabilitation support groups to ensure persons with disabilities get services according to their needs.
\end{abstract}

Key word; Community Based Rehabilitation, Persons with Disabilities

\section{INTRODUCTION}

At this time, persons with disabilities in Baturetno Village as well as those in other villages in Yogyakarta Special Province still face problems related to their welfare. Characteristic of persons with disabilities in Baturetno Village, as well as the average condition of persons with disabilities in Bantul District, are: the absence of valid data regarding the number and details of the characteristics of the problems and needs of persons with disabilities; there are still many persons with disabilities (PwDs) who do not have identity cards; still facing psychological problems; such as not daring to leave home, do not have self confident, fear; comes from families with low socioeconomic and health levels; generally have low levels of education; the productivity of human resources of persons with disabilities is relatively low because they have not had opportunities to get job training; there are still social and cultural barriers, there is discrimination come from the family and community, the have environment and physical barriers, there is lack of accessible public facilities; have no ability to run their own business because of the absence of skills, difficulty in obtaining access to capital; the ability to do business marketing is still low. Unavailability of valid data and lack of identity cards give impact to PwDs unable to obtain services from government. Health insurance, education programs, training programs and economic empowerment programs are inaccessible for persons with disabilities. This is what makes the welfare of persons with disability still in a state of concern.

\section{PROBLEM SOLVING}

The problem solving's framework to address the problems to empower persons with disabilities. Law of Persons With Disabilities No. 6 year 2016[1] and Biwako Millennium Framework for Action (BMFA) emphasizes to the inclusive programs in all sector, handling and service delivery to the PwDs requires the role of various parties, especially the role of government and society. The various parties is expected to have attention in overcoming various problems of PwDs. They are the village government, 
supported by community organizations at the village level. Until now the government and the village community have not played their roles and have not given attention to the problems of persons with disability, this is because they have not sufficient understanding related the disability issues.

The KKN-PPM (Kuliah Kerja Nyata Program Pembelajaran Masyarakat/The Student Course Work of Community Learning Programs) is expected to provide a model for providing awareness raising and improving the capacity of the village government and village communities to improve the welfare of persons with disabilities. Village government and Village communities in Baturetno need to understand the various issues of PwDs. The important disability issues are government policies, in national, provincial and district level that can be as basis for planning government programs and budgeting designed for persons with disabilities. By understanding the problems, regulation and programs of government in the national, provincial and district level, if there are persons with disabilities in the Village, Government and Community Organizations in the village can facilitate to bring the service programs closer to persons with disabilities, thus PwDs can improve their welfare. Personnel that is involved in the activities are village government, PKK and Karang Taruna organizations and persons with disabilities or parents with disabilities in the Village. They are together formed Community Based Rehabilitation Group. The community-based Rehabilitation Group (CBR) is a group within the community to provide an effort to restore the functioning of persons with disabilities. The Community Based Rehabilitation Group (CBR) plays a role in:

A. To enable self-reliance in persons with disabilities, families and communities in the village. The CBR group [2] strives for persons with disabilities to have access to the government services based on their need, while they remain in the community and got supported from their communities, and enjoy a lifestyle like others in the society. They can participate in decisions making of government policy that give impact to themselves, their families and the communities.

B. To give education to the community in making integration with the persons with disabilities. The Community Based Rehabilitation/CBR group will provide information about the problems faced by PwDs and the possible ways to address them. So that community's attitudes to the PwDs will change, and they can accept persons with disabilities as part of the communities. This group will continually pay attention and facilitate PwDs in the village and also to try to obtain services from the government as well as from the communities, thereby improving the welfare of PwDs.

\section{METHOD OR CONCEPT OF ACTIVITIES USED FOR PROBLEM SOLVING}

Method or concept of activities used for problem solving are the first step is organizing community-based rehabilitation groups. This group will come from village government personnel, personnel from PKK and personnel from Karang Taruna and persons with disabilities or parents of persons with disabilities in the Village. Second, strengthening community-based rehabilitation groups, by providing disability awareness training, introducing legislation related to the protection and fulfillment of the rights of persons with disabilities, training on the role of community-based rehabilitation groups to ensure persons with disabilities receive services in accordance with their needs. Third, Next step: Pilot Project of CBR Group by doing activities: 1) Data collection and assessment of the needs of persons with disabilities in Baturetno the Village. 2) Economic empowerment of PwDs and their families. Reinforcement includes providing vocational training based on PwDs choise. The alternatif vocational training that is provided are cooking and craft . 3) The strengthening of business groups run by persons with disabilities is done through the provision of entrepreneurial and business management training, so that PwDs can understand how to run their own business. 4) The Strengthening savings and loan group by doing through savings and loan management training.

To support the acceleration of the run of communitybased rehabilitation groups, it is necessary to provide assistance in the formulation of programs and activities of community-based rehabilitation groups to ensure persons with disabilities obtain services in accordance with their needs. The CBR program consist of data collection, refferal and advocay. In order to become a program sustainability, CBR group can try to access village government budget, subdistrict budget funds and district budget funds with support to ensure people with disabilities receive services in accordance with their needs.

\section{PRODUCT AND OUTPUT OF KKN-PPM ACTIVITIES}

This KKN-PPM activity is expected to improve the welfare persons with disabilities in the Village. To achieve the product of this program that thare is system for improving the welfare of people with disability, done by optimization the role of Community-Based Rehabilitation groups in village. The activities of KKN PPM can produce: First, 
establishment of Community Based Rehabilitation Group (CBR). This group will come from village government personnel, personnel from PKK and personnel from Karang Taruna and persons with disabilities and/or parents persons with disabilities in the Village. The Community Based Rehabilitation Group (CBR) is a group within the community to provide efforts to restore the functioning of persons with disabilities who are physically, mentally, psychologically and socially disadvantaged, by relying on the role of family and community groups, and utilizing various initiatives, potential, and community resources.

Figure 1.

Method or Concept of Activities Used for Problem Solving

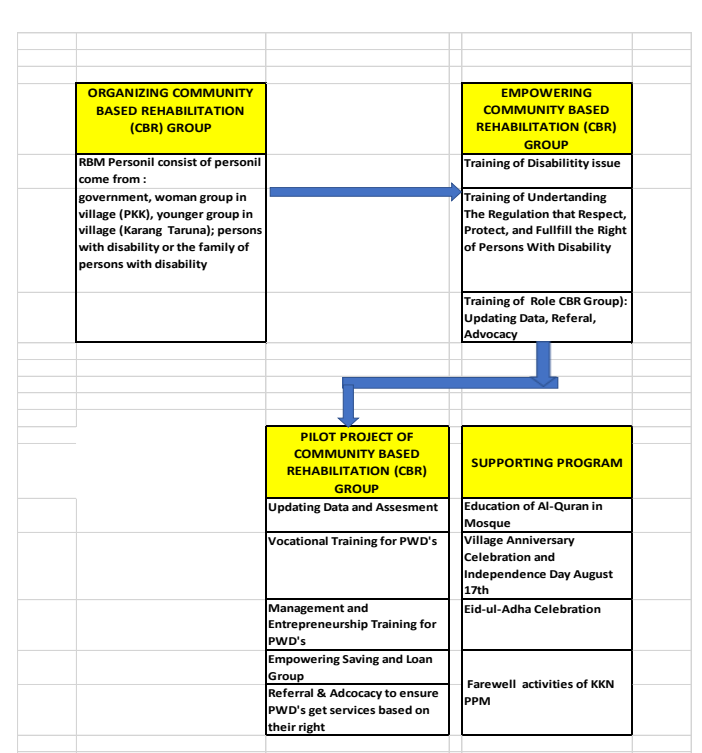

Second, establishment of an independent business group run by persons with disabilities and nondisabled communities in inclusive activities. This group is expected to also be able to produce food or craft product, manage finance, conduct marketing, and manage human resources of the business group. Third, Formation of savings and loan groups consists of members of community-based rehabilitation groups (CBR) and the community in Baturetno Village. The saving and loan group can facilitate community in the Village to get fund for running their business.

Output of KKN PPM are: First, Improved the understanding of community based rehabilitation groups in disability issues. The program can be done by giving disability issue training, introduction of laws and regulations related to the protection and fulfillment of the rights of persons with disabilities, and training of CBR group roles. Second, The existence of pilot project activities for persons with disabilities by community-based rehabilitation groups, who will carry out data collection and assessment of persons with disabilities; strengthening the qualiti of human resource persons with disability in the village by providing vocational training; establishment of business group; providing entrepreneurial knowledge and business management training to persons with disabilities; establishment and strengthening of saving and loan groups through savings and loan management training; Doing referral and advocacy that ensure people with disabilities get the government services. Third, the existence of programs and activities of community-based rehabilitation groups, which ensures persons with disabilities can be access the government services by data collection, referrals and advocacy. Government service for persons with disability can be health services, education, employment, rehabilitation etc. Fourth, suporting in Increased income of PwDs, so that their welfare can increase and they can live independently.

\section{IMPLEMENTATION OF PROGRAMS}

A. Organizing Community Based Rehabilitation (CBR) Group.

Community Based Rehabilitation (CBR)

GROUP is formed with membership consisting of government, women group in village (PKK), younger group in village (Karang Taruna); persons with disability or the family of persons with disability. PKK is Family Welfare Development, abbreviated PKK, is a community organization that empowers women to participate in the development of Indonesia. Karang Taruna is a social organization of youth development which grows and develops on the basis of social awareness and responsibility from, by and for society, especially young generation in village area and especially in social welfare business. The CBR group formed in order the persons with disability in the village can easily obtain information and programs from the government.

\section{PILOT PROJECT OF COMMUNITY BASED REHABILITATION (CBR) GROUP}

A. Dissemination Socialization Disability Issue. KKN PPM is hoped can improve the understanding of CBR group on disability issues. The program can be done by giving disability issue training, introduction of laws and regulations related to the protection and fulfillment of the rights of persons with disabilities, and training of CBR group roles. Dissemination of Disability Issues with the theme of "Improving the Role of Government and Village Communities in Improving the welfare of Persons with Disabilities" aimed to educate government and community in the Baturetno village about the diversity of Disability, the causes of Disability and the rights of PwDs. This socialization event is held concern on 
disability regulation because there is a link between Disability Issues and regulation so that persons with disabilities have equal opportunities and rights that are guaranteed by the regulation. The partisipant of the dissemination consist of CBR (Community-Based Rehabilitation) representatives, families of persons with disabilities, and persons with disabilities. This activity give information to the government and the village community concerning who is persons with disabilities and what is their characteristic. This activity also informed regulations that protect and fulfill the rights of PwDs, at national, provincial and district levels. The national legislation is Law no. 8 year 2016 [1] on persons with disabilities. The local regulation consist of Local regulation of Yogyakarta Province No. 4 Year, The protection and fulfillment of the rights of persons with disabilities; Local Regulation of Bantul District No. 11 of 2015 The fulfillment of the rights of persons with disabilities; Local Regulation of Kulon Progo district No.3 Year 2017 on the accomplishment of protection of disability; Local Regulation of Gunungkidul district No 9 Year 2016 on the accomplishment of protection and fulfillment of the rights of PwDs. The result of this activity is the CBR group and the Village Government can ensure that persons with disabilities receive services in accordance with their needs; families and persons with disabilities know the rights to be gained to obtain the services they need. This activity also is hoped that in the future the village government can take the policy by considering persons with disabilities. Educate the persons with disabilities and their families also aim to improve their undertanding on the rights of persons with disabilities, and how to get their right.

\section{B. Data Collection.}

Until now almost in all regions in Indonesia how many persons with disabilities and their characteristic still cannot be known. This is because of there has not been a valid data collection system for persons with disabilities that is valid. Data collection is still a problem that needs improvement in the future. This fact is due to the lack of understanding of PwDs by the government and the community including officers who do the data collection. It is not surprising that the number of persons with disabilities that is recorded at the district, sub district and in the village in small numbers. Based on Word Report on Disability in 2011, the number of persons with disabilities is $15 \%$ of the total population. Unavailability of valid data causes PwDs to be unable to obtain services from government programs. Health insurance, education programs, training programs and economic empowerment programs are inaccessible to persons with disabilities. This is what makes the welfare of people with disability still in a state of concern. The KKN-PPM program provides examples of how the data collection forms are made and how to perform data collection and make assessment of the needs of persons with disabilities. The data was collected with the CBR group, supported by the village head. Data collection done by RBM groups is more effective, because they know citizens and regions better, so that data collection can reach the target. The results of data collection in Baturetno Village in Bantul district Yogyakarta Province are: There are 94 persons with disabilities in Baturetno village spread in 8 dukuh., 33 persons of them do not have health insurance.

\section{Vocational Training.}

Craft skill and Culinary vocational training aims to enable the PwDs to be self-reliant and have skills, so that the future PwDs can run their own business and can live independently. In this program there are training of decoupage technique, The technique for sticking tissue napkin on woven pandanus. The program also provides culinary skills training to provide the possibility of persons with disabilities work in the culinary field. Culinary skill training is given training on making food with raw material mocaf flour (Modified Cassava Flour). Skills training is conducted in inclusion by involving communities and families with disabilities. It is hoped that persons with disabilities can establish self-employment can also be supported by their families and their local residents.

\section{Saving \& Loan Management Training.}

Baturetno village has already had saving and loan group, which provides the services to the citizens who will save the funds and need loan. So far this savings and loan group only provide services to the general public. Persons with disabilities that have never had the opportunity to access loan from these groups. The purpose of this activities is to inform to the community that the persons with disabilities can become saving \& loan group in the Village. The saving \& loan group is responsible for managing savings and loan funds provided by the village government. KKN-PPM conducts savings and loan training for savings and loan group managers that is hoped that this saving and loan group can also provide services for PwDs or their families.

\section{E. Entrepreneurship Training.}

This entrepreneurship program is provided to persons with disabilities and their families, with the hope that people with disabilities who are starting an independent business gain a basic understanding of how to manage a business. Persons with disabilities and their families are also be given an understanding of the fundamentals of management, that consist of marketing management, financial management, marketing management and operational management. 
Marketing management is expected to provide a basic understanding of how to sell products, financial management provides an understanding of how business financial management, including how to allocate funds and obtain sources of funding, operational management covering how to operate its business, and human resource management provides an understanding how to manage human resources in the business.

\section{F. Referrals and Advocacy.}

Referral is a program that is done after the data collected. Based on the data collection can be identified how many persons with disability, how many persons with disability that have not got the government or community services. The Referrals program is implemented after collecting data of PwDs. The village government and CBR (community-based rehabilitation) follow up to communicate to the service provider. Based on this data collection that there are 94 people with disability, 33 of them have not been health insurance, CBR groups can follow up to make refferal to social and health department of government organization in district level. If there are PwDs that haven't had health insurance, CBR group can follow up by making refferal to the government to receive health insurance. CBR group can make refferal to other service provider, if there are persons with disabilities need mobility equipment like wheelchaire, CBR group can make refferal to organization that provide wheelchair. The CBR also can do advocacy. Advocacy is an activity by an individual or group which aims to influence decisions within political, economic, and social systems and institutions. Advocacy can include many activities that a person or organization undertakes including media campaigns, public speaking, commissioning and publishing research, lobbying. Lobbying is a form of advocacy where a direct approach is made to legislators or any istitution. When children with disabilities have difficulities in going to school, CBR group can make communication to the school to get the way out of the problem.

\section{ADDITIONAL PROGRAMS KKN-PPM}

\section{A. Education Al-Qur'an.}

Education Al-Qur'an program is one of the auxiliary work program that aims to foster religious life by involving the community, include people with disabilities and their families. Religious education is done by giving education for worship, reading and interpretation of Al-Quran.

\section{B. Republic of Indonesia Independence Day Celebration.}

The commemoration of the 72nd anniversary of Indonesia's independence day is one of the programs in KKN PPM. In this activity the KKN PPM program involves the participation of persons with disabilities in activities undertaken including participation in parades and bazaars. In this activity also conducted awareness raising activities to socialize to the community about the existence of persons with disabilities with various problems. This activity was carried out during the parade with various slogans to get attention from various parties to ensure the protection and fulfillment of the rights of PwDs.

\section{Meid-ul-Adha Celebration.}

KKN PPM students are also active in participating in Eid-ul-Adha celebrations. There are various activities carried out. The activities are are takbir parades, Ied prayer and slaughter animal sacrifice Takbir parades is done by involving children and the participation of PwDs. Meanwhile, Ied prayer is done in the village of Baturetno which then followed by slaughter of qurban animals. The results meat of animal slaughtering are distributed to vulverable community, including persons with disabilities.

D. Closure and Farewell.

As a closer of the program KKN PPM held the night farewell. The purpose of holding the event is as a means to establish friendship to the village government and community in the village. The implementation event was themed "The Night to Remember" Anniversary Night of Indonesia \& Parting KKN UMY "A Night to Remember". In the event, KKN UMY collaborated with youth organization in its implementation. This event involves the village government, communities also invited persons with disabilities, who has been willing to cooperate, so that the KKN PPM program focusing on PwDs can work well.

\section{CHALLENGES AND BARRIERS}

This program encounters several challenges, including the challenges come from the community and families of persons with disabilities who still do not give trust to persons with disabilities to participate in the community. The program also faces challenges with the time available personnel in the CBR group. This voluntary activity is certainly conducted when CBR personnel have spare time, so the continuity of this activity has not been able to run smoothly. Willingness and capabilities of personnel of CBR group to support Persons with disabilities in the village to get government services at village, sub-district, district and provincial levels will determine the time that is needed by the person with disabilities to access 
government services. Funding for the implementation of CBR group activities is also a difficult challenge. But these challenges will be faced with continuous socialization and communication to the parties.

\section{CONCLUSIONS AND RECOMMENDATIONS}

Based on the experience of KKN PPM implementation, it can be concluded that the problems of the welfare of people with disability in various regions are still a problem that has not been handled, therefore still require the attention of various parties. Handling services for people with disabilities will be more effective when involving the government and the nearest community. The availability of human resources in the village is a tremendous strength in ensuring the fulfillment of the rights of PwDs. Based on the findings of the PPK KKN program, the district government is needed to suport and strengthen community-based rehabilitation group programs in the village, which will support the acceleration of protection and the fulfillment of the rights of persons with disabilities.

\section{REFERENCES}

[1] "Law no. 8. Year Concerning Disabilities." 2016.

[2]“https://pilarbulan.wordpress.com/2012/08/31/rah abititasi-sosial-berbasis-masyarakat-pekerjaansosial/ diunduh pada 10 Mei 2016." [Online].

Available: https://pilarbulan.wordpress.com/2012/08/31/rah abititasi-sosial-berbasis-masyarakat-pekerjaansosial/ diunduh pada 10 Mei 2016.

[2] Republik Indonesia. 2011. Undang-Undang Nomor 19 tahun 2011 tentang Pengesahan Convention on the Rights of Persons with Disabilities (Konvensi mengenai Hak-Hak Penyandang Disabilitas). Lembaran Negara Republik Indonesia Tahun 2011 Nomor 107. Sekretariat Negara. Jakarta.

[3] Republik Indonesia. 2012. Peraturan Daerah Provinsi Daerah istimewa Yogyakarta Nomor 4 Tahun 2012 tentang Perlindungan dan Pemenuhan Hak-Hak Penyandang Disabilitas. Lembaran Daerah Provinsi Daerah Istimewa Yogyakarta Tahun 2012 Nomor 4. Sekretariat Daerah Provinsi Daerah Istimewa Yogyakarta. Yogyakarta.

[4] Republik Indonesia. 2015. Peraturan Daerah Provinsi Kebupaten Bantul Nomor 11 Tahun 2015 tentang Pemenuhan Hak-Hak Penyandang Disabilitas. Lembaran Daerah Kabupaten Bantul Tahun 2015 Nomor 53. Sekretariat Daerah Kabupaten Bantul Yogyakarta
[5] Republik Indonesia. 2016. Undang-undan No. 8 Tahun 2016 tentang Penyandang Disabilitas. Lembaran Negara Republik Indonesia Tahun 2016 No. 69 Kementrian Sekretariat Negara Republik Indonesia Jakarta. 